\title{
Re-Os and highly siderophile element systematics of Archean komatiites from Kambalda (W-Australia)
}

\author{
C. GERRITZEN', M. FisCHER-GÖDDE', H. BECKER ${ }^{2}$, C. \\ MÜNKER', H. SMITHIES ${ }^{3}$, P. GLEISSNER ${ }^{2}$
}

Inst. f. Geol. und Min., Univ. of Cologne, Germany

'Inst. f. Geol. Wissenschaften, FU Berlin, Germany

${ }^{3}$ Geol. Surv. of Western Australia, East Perth WA, Australia

The Kambalda komatiites are part of the $2.7 \mathrm{Ga}$ late Archean greenstone belt in Western Australia. They host magmatic sulphide ore deposits. High degrees of partial melting and a comparatively low S content in the komatiite mantle source suggest that the initial melts were likely sulphur-undersaturated. Thus, in order to explain the formation of sulphide depositis it has been proposed that the komatiites may have reached sulphur saturation by assimilation of sediments [1]. This scenario, however, was difficult to reconcile with Re-Os and $\mathrm{S}$ isotope data that did not provide evidence for assimilation of crustal components or sediments $[2,3]$. In order to place further constraints on the origin of Kambalda komatiites and sulphide ores, we determined osmium $\left({ }^{187} \mathrm{Os} /{ }^{188} \mathrm{Os}\right)$ isotope compositions and concentrations of highly siderophile elements (HSE) for a suite of 11 komatiites.

Concentrations of compatible HSE (Os, Ir, Ru) decrease with decreasing $\mathrm{MgO}$ and $\mathrm{Ni}$, whereas incompatible HSEs $(\mathrm{Pd}, \mathrm{Au}, \mathrm{Re})$ show no systematic variation with $\mathrm{MgO}$ or other indicators for fractional crystallization. The measured ${ }^{187} \mathrm{Os} /{ }^{188} \mathrm{Os}$ compositions of the Kamabalda komatiites range from 0.1114 to 0.6568 , with ${ }^{187} \mathrm{Re} /{ }^{188} \mathrm{Os}$ between 0.092 and 11.84. The ${ }^{187} \mathrm{Os} /{ }^{188} \mathrm{Os}$ compositions obtained for 3 of the studied samples are significantly more radiogenic compared to values reported in [2]. In a Re-Os isochron diagram our samples plot along a previously presented isochron, defined by sulphide ores and one bulk komatiite, yielding an age of $2706 \pm 36 \mathrm{Ma}$ and a chondritic ${ }^{187} \mathrm{Os} /{ }^{188} \mathrm{Os}$ composition with $\gamma \mathrm{Os}$ of $-0.10 \pm 0.32$ [2]. Using this age as crystallization age, the initial Os isotope compositions of the komatiites range from 0.0575 to 0.1110 , translating into significant deviations from the chondritic trajectory at the time of emplacement ( $\gamma \mathrm{Os}$ from +2.4 to -50 ). The radiogenic ${ }^{187} \mathrm{Os} /{ }^{188} \mathrm{Os}$ and high $\mathrm{Re} / \mathrm{Os}$ obtained for some komatiites in this study are best explained by assimilation of crustal material and may therfore point towards a crustal origin of sulphur in the Kambalda ores.

[1] Huppert et al. (1984) Nature 309, 19-22. [2] Foster et al. (1996) Nature 382, 703-706. [3] Bekker et al. (2009) Science 326, 1086-1089. 